日臨外会誌 $67(4), 880-884,2006$

症

例

膵仮性囊胞内出血により hemosuccus pancreaticus を呈した 1 例

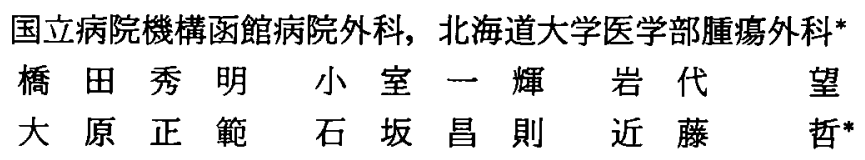

症例は70歳, 男性. 多量の飲酒歴があり，慢性膵炎にてフォローをうけている．また 胃海喈にて幽門側胃切除術 (再建：Billroth II 法)を施行されている. 平成15年 4 月吐血 のため当院入院, 腹部 CT で径 $6 \mathrm{~cm}$ 大の脾動脈瘤を認めたが内視鏡検查にて異常を認 めなかった。 十二指腸乳頭の観察は行えず，脾動脈瘤と消化管出血の関連が証明できな かったため経過観察となった。その後, 吐下血のため10月に再入院，内視鏡検査では出 血を確認できなかったが，下血が遷延するため最終的に脾動脈瘤が膵内に穿破したこと による消化管出血と判断し, 膵体尾部脾切除を施行した，病理では，脾動脈は弾性瀻維 を欠如しており，膵仮性烡胞内に穿破して仮性動脈瘤を形成し膵管内に出血を生じたも のと推測された，慢性膵炎の経過中の消化管出血においては膵管を介する出血である hemosuccus pancreaticus を念頭におく必要があると思われた。

索引用語：hemosuccus pancreaticus, 脺仮性蘘胞内出血, 脾仮性動脈瘤

\section{緒言}

Hemosuccus pancreaticus は脺管を経由し十二指 腸乳頭からの消化管出血を呈する比較的稀な病態であ る ${ }^{1}$. Hemosuccus pancreaticusをきたす最も多い原 因は膵仮性辜胞内出血によるもの光とされ，十二指腸 乳頭からの出血を内視鏡的に確認することが, hemosuccus pancreaticus を疑う契機となる ${ }^{31}$. 自験例 は脾動脈瘤を指摘されていたが，間欠的な消化管出血 に対し絽り返し内視鏡検查を施行したが, Billroth II 法吻合後のため十二指腸乳頭の確認が行えず, 出血源 の同定に苦慮した 1 例を経験した。慢性膵炎の経過中 て，原因不明の消化管出血を認める場合は，hemosuccus pancreaticus を念頭において診療をすすめるべき であると考えられたので若干の文献的考察を加え報告 する。

\section{症例}

患者：70歳, 男性.

主訴：吐下血。

既往歴：昭和52年, 胃潰慯のため幽門側胃切除術施

2005年12月 5 日受付 2006年 2 月 15 日採用

〈所属施設住所〉

干041-8512 函館市川原町18-16
行 (再建：Billroth II 法吻合)。平成 2 年, 胆石症のた め胆蓑摘出術施行. 平成 8 年, 輸入脚症候群のためフ ラウン吻合術を施行されている. 平成14年, 肺血栓症 のため当院入院の既往あり. 平成 4 年より慢性膵炎に て他院でフォローをうけている.平成12年より肺気腫, 平成14年より糖尿病のため当院フォロー中である。

飲酒歴： 3 年前まで, 日本酒 2 合/日.

現病歴：平成15年 4 月 3 日，吐血あり。 4 月 4 日近 医受診後, 救急車にて当院搬送, 血液検查で $\mathrm{Hb} 6.0 \mathrm{~g} /$ dl と著明な貧血を認め入院となった．入院時の腹部 CT で径 $6 \mathrm{~cm}$ 大の脾動脈㿔を指摘されていたが，上 部・下部内視鏡検査では明らかな出血源を同定できな かった. 上部消化管内視鏡検査では, Billroth II 法吻合 後であったため, Vater 乳頭の観察は行えなかった。脾 動脈瘤に対しては，消化管出血との関連を想定してい なかったことと, 複数回の手術の既往があり, 脾門部 に著明な側副血行路を認めていることから手術が困難 であると考えられたため経過観察とした，入院後，吐 血は消失したため 4 月14日退院となった，退院後，下 血を認めたため 4 月 16 日再度入院となったが, 精査中 に食道穿孔を発症し 5 月10日手術を施行した。街後, 下血や貧血の進行を認めず， 7 月 5 日退院した。外来 フォロー中, 再度下血を認めたため 10 月 6 日入院とな 

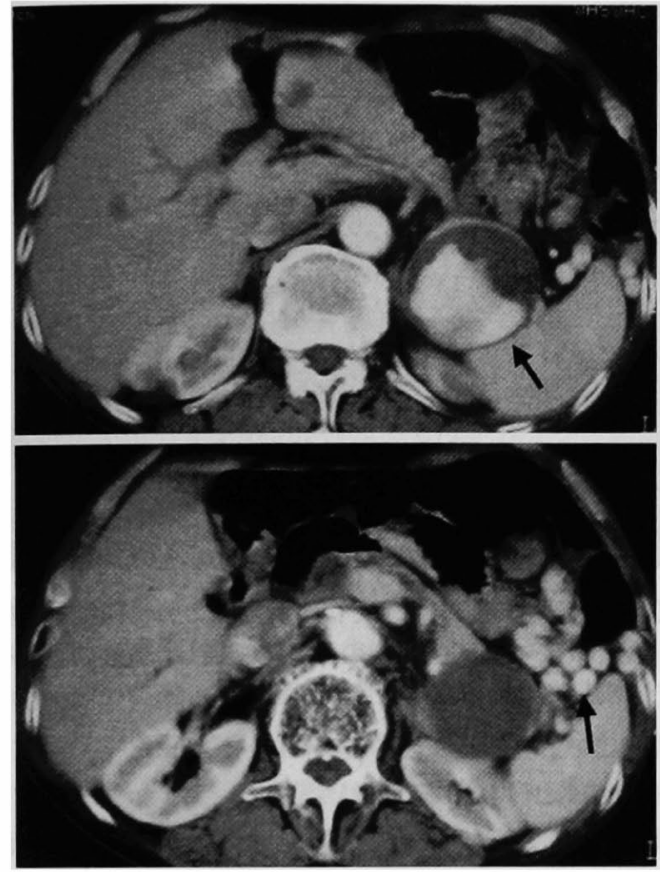

図 1 腹部 CT 検査：a）内部に血栓化を伴った径 $6 \mathrm{~cm}$ 大の脾動脈瘤を認める(矢印)。 b) 脾門部に 側副血行路と思われる血管の拡張を認める（矢 印).

った.

入院時現症：身長 $158.5 \mathrm{~cm}$, 体重 $46.5 \mathrm{~kg}$, 血圧 $140 /$ $100 \mathrm{mmHg}$, 脈拍 $60 /$ 分整, 体温 $36.2^{\circ} \mathrm{C}$, 眼瞼結膜に貧 血なく，眼球結膜に黄疸を認めなかった．腹部は上腹 部正中に手術痕を認めるが, 圧痛なく, 腫瘤も触知し なかった。

入院時検查所見 : $\mathrm{Hb} 10.1 \mathrm{~g} / \mathrm{dl}$, 血小板 $8.7 \times 10^{4} \mu \mathrm{l}$ と軽度の貧血と血小板減少を認めた。

上部消化管内視鏡検查：食道, 残胃, 吻合部に出血 性病変を認めず, 凝血槐も観察されなかった。

腹部 CT 検查：入院時の腹部 CT では, 内部に血栓 化を伴う径 $6 \mathrm{~cm}$ 大の脾動脈瘤と, 脾門部周辺に著明 な側副血行路の形成を認めた（図 1 ).

血管造影検査：脾動脈瘤を認めたが，消化管出血の フォーカスを認めなかった（図 2 ).

出血シンチ, Meckel 顋室シンチ：出血部位の同定 はできなかった。

試験開腹: 術中, 上部消化管内視鏡検査を施行, 用 指的に内視鏡を誘導し, 極力輸入脚の観察を行うも, 可視範囲内に出血を認めなかった。

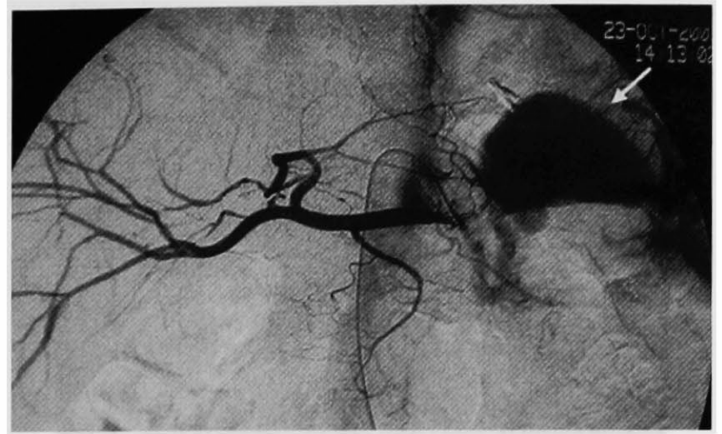

図 2 血管造影検査：脾動脈瘤を誌める (矢印) が, 消化 管出血のフォーカスは同定できなかった.

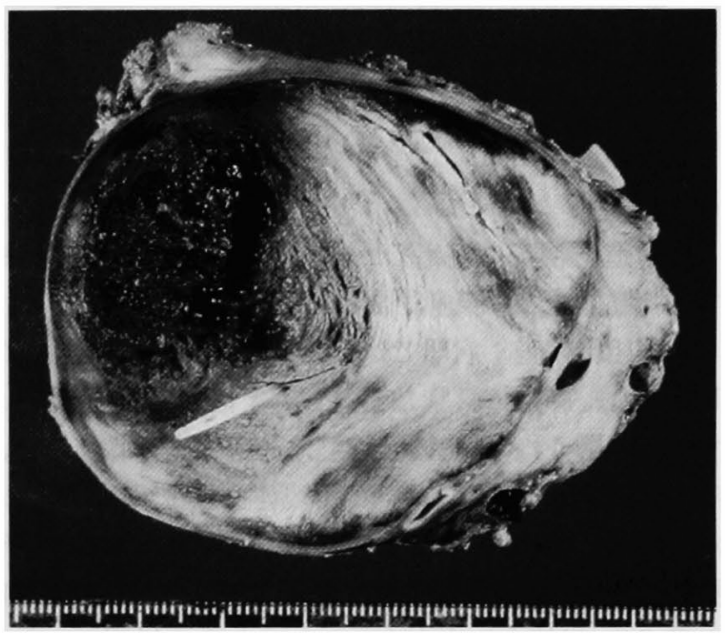

図 3 切除標本：動脈瘤の割面は層状に基質化した血栓 を認め, 内部に新鮮血を認めた。

以上の検查所見から，脾動脈瘤を認めていること， 他に消化管出血のフォーカスを同定できなかったこと で, 脾動脈瘤から膵管を介しての出血を想定し, 平成 15年11月26日, 手術を施行した。

手術所見：L字切開にて開腹, 横行結腸から大網を 切離し, 横行結腸間膜を露出すると, 脾門から横行結 腸間膜へ抎張した側副血行路を数本認めた.つづいて, 脾動脈中枢部を露出し，テーピングしたあと脾門から の側副血行路を結紮切離し, 脾・膵体尾部を脱転した。 脾静脈は閉塞していた。脾動脈を根部近くて処理し, 膵を離断，膵管は結惄し，膵断端を縫合した．左横隔 膜下にドレーンを插入し閉腹した。手術時間は 4 時間 43分, 出血量は $1,600 \mathrm{ml}$ であった.

切除標本：動脈瘤の割面は層状に基質化した血栓を 認め, 内部に新鮮血を認めた（図 3 ). 


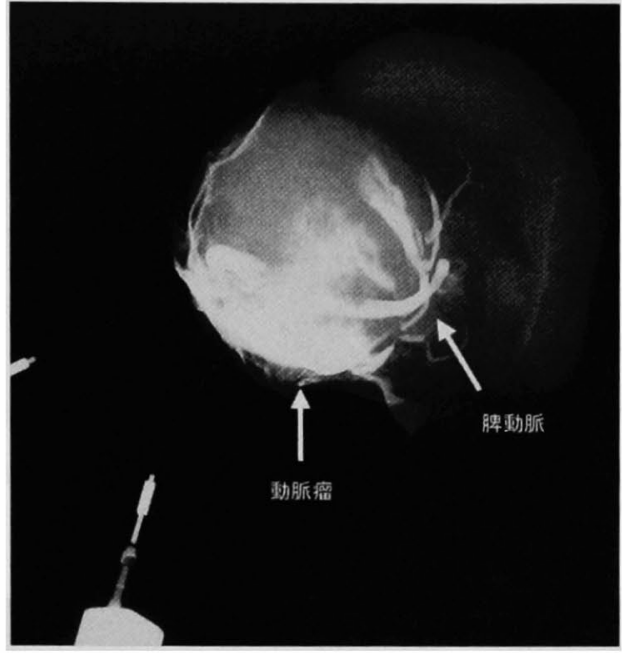

図 4 標本造影検査 : 摘出した検体の主脺管か らの造影で, 脾動脈瘤との交通を認めた。

摽本造影検査：摘出した検体の主膵管からの造影 で, 脾動脈瘤との交通を認めた（図 4).

病理組織検査：病理では, 脾動脈の弾性瀻維を欠如 しており, 膵内の襄胞と交通し, 仮性動脈瘤を形成し ていた（図 5 )。胼内の哓胞壁は菲薄化した膵実質で, 内部に上皮を欠如しており，膵仮性裹胞の所見であっ た．また，膵管内には血液の混入を認めた，以上の所 見から，脾動脈が膵仮性襄胞内に穿破して仮性動脈瘤 を形成し、膵管内に出血をきたしたものと推測された。

術後経過: 術後経過は順調で, 術後29日目に退院と なり，現在まで消化管出血の再発なく経過中である.

\section{考 察}

膵仮性葶胞は，慢性または急性脺炎の10〜20\%に発 生し，さらに嚄胞内出血は，その $6 \sim 10 \%$ に併発する といわれている゙． 顀胞内出血の機序としては，1）㖶 胞内圧の上昇による嚄胞壁の壊死のため表在血管から 出血する，2）膰の炎症性病変が脾動脈, 胃十二指腸 動脈などに，仮性動脈瘤を形成しこれが破綻し出血す る，3）仮性襄胞が膵管, 胃, 十二指腸などと㾇孔を つくり消化液が逆流して膵蛋白分解醉素が活性化され 䙵胞壁の血管にびらんを生じて出血する機序が考えら れており5), 自験例は 2)の機序による。ささらに㖶胞内 出血の転機には 1 ）壤胞内のみに出血するもの，2） 腹腔内に穿破するもの，3）近接消化管へ穿破するも の，4）胆管に穿破し hemobilia をきたすもの，5） 主膵管と交通して十二指腸乳頭部から出血をきたすも のがある3!。これらのうち 5) は hemosuccus pan-

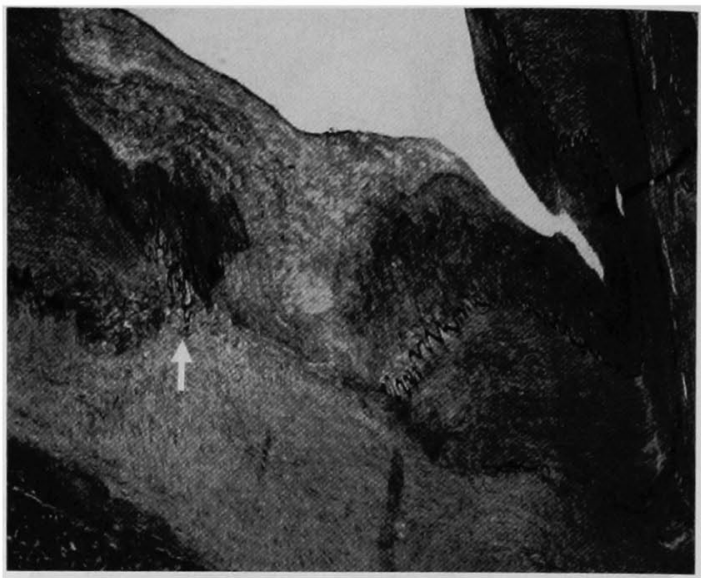

図 5 病理組織像：病理では，脾動脈の弾性織維を欠如 (矢印)しており，膵内の萁胞と交通し，仮性動脈㿔を 形成していた（EM 染色 $\times 20 ）$.

creaticus と呼ばれる6).

本邦の膵仮性亯胞を伴った hemosuccus pan creaticus の報告は検索しえたかぎり自験例を含め41 例で, 年齢は29 83歳, 平均52.1歳, 男性38例, 女性 3 例で, 多量の飲酒歷を有するものは 40 例中 31 例あっ た。症状は, 上腹部痛・心䆟部痛, 吐下血が多く, 腹 部腫瘤, 左季肋部痛などがみられた。術前に hemosuccus pancreaticus と診断しえたものは19例であった. 責任血管は過去の報告例のうち記載のあるものをまと めると脾動脈が 15 例と最も多く，胃十二指腸動脈が 5 例, 背側膵動脈 3 例, 前上萃十二指腸動脈 2 例, 総肝 動脈・左胃大網動脈・上腸間膜動脈が各 1 例であった。 1 年以上の病脳期間を有するものは 16 例あり, 最長 9 年で, 自験例においても吐下血を呈してから手術にい たるまでに 6 カ月を要した. Hemosuccus pancreaticusの猃断には上部消化管内視鏡検査で Vater 乳頭ないし副乳頭からの出血の確認が重要であり, 消 化管出血の原因として hemosuccus pancreaticus 疑う直接的な契機となる ${ }^{3}$. しかし，十二指腸乳頭から の出血は間欠的であり, 確認には数度の内視鏡検査を 要することもある，過去の報告によると 41 例中，出血 を確認できたものは22例であり，確認できないことも 多い.一方, 腹部造影 CT では仮性嘦胞内に出血を示 す高吸収域や，血管造影では膵周囲の血管に動脈瘤や extaravasationを認めることが多いが， hemosuccus pancreaticus の間接的所見であり，十二指腸乳頭から の内視鏡的な出血の確認ができなければ他の消化管出 血の除外診断が必要である. 自験例においては，胃切 
除後の Billroth II 法吻合後であったため十二指腸乳 頭からの出血の確認は困難であった.また,腹部 CT ゃ 血管造影で脾動脈瘤は指摘されていたが，当初，脺管 を介しての出血が念頭になく消化管出血の原因として 想定していなかったため診断・治療が遅れたことは否 めない，䏽管を介する消化管出血は，臨床で遭遇する 機会が比較的少ないため診断が遅れる傾向にあると思 われ，慢性膵炎，膵仮性菜胞の経過観察中の消化管出 血には，内視鏡検查で十二指腸乳頭からの出血を確認 できない場合でも，腹部造影 CT で脺仮性美胞内への 出血や, 血管造影で膵周囲の血管に動脈瘤, extravasationの所見を認める場合には, hemosuccus pancreaticus を念頭におく必要がある。

治療は，㐮胞・動脈瘤を含めた膵切除が原則で，40 例中26例で膵頭十二指腸切除・膵体尾部切除が施行さ れており，自験例でも体尾部切除を施行し，経過は良 好である，一方で，膵切除は繰り返す膵炎による炎症 性変化のための必ずしも容易ではないことや，膵機能 温存の点などから，最近では動脈塞栓術による治療例 の報告もみられる7)-9). 今後はまず動脈塞栓術を施行 し, 手術は塞栓術の不成功例や, 塞栓術後の経過中に 感染や再出血を生じた症例が対象となってくると考え られ，自験例においても動脈塞栓術を試みる価值があ ったものと思われる。

\section{結 語}

Billroth II 法吻合後のため内視鏡検査で十二指腸乳 頭の確認が行えず，出血源の同定に苦慮した，膵仮性 襄胞内出血による hemosuccus pancreaticus を呈し た1例を経験したので文献的考察を加え報告した。

本稿の要旨は，第82回北海道外科学会 (平成16年 2 月札 幌)にて発表した。稿を終えるにあたり病理診断に際してご 指登を賜りました病理部石舘卓三先生に深謝いたします。
文献

1) Sandblom $P:$ Gastrointestinal hemorrhage through the pancreatic duct. Ann Surg 171:61 $-66,1970$

2）沼尻浩二，仙波真吾，関口忠司他：Hemosuccus pancreaticus を呈した膵仮性烡胞の1例. 日臨外 会誌 $62: 790-794,2001$

3）西田宏二, 明石隆吉：膆仮性英胞内出血. 消内視 鏡 $6: 1076-1079,1994$

4) Cahow CE, Gusberg RJ, Gottlieb LJ : Gastrointestinal hemorrhage from pseudoaneurysms in pancreatic pseudocysts. Am J Surg $145: 534$ $-541,1983$

5）小林道也, 緒方卓郎, 荒木京二郎他 : 腹腔内出血 を来した膵仮性变胞の 1 例. 日消外会誌 $27: 912$ $-916,1994$

6）佐藤 力, 遠藤 剛，土屋豊一他：十二指腸乳頭 部より上部消化管出血をきたした偽動脈瘤を伴う 膵仮性美胞内出血の 1 例. 胆と脺 $6: 1421-$ 1426, 1985

7）桑田陽一郎, 廣田省三，長谷川義記他：動脈塞栓 術により治療しえた hemosuccus pancreaticus をきたした脾動脈仮性動脈瘤の 1 例. 臨放 38 ： 1475-1478, 1993

8）野村俊之, 板橋 司，松尾隆広他：動脈塞栓術に て止血し得た hemosuccus pancreaticus $の 1$ 例. 胆と膵 $25: 671-674,2004$

9）金田宗久，松本賢治，和多田晋他：Hemosuccus pancreaticus を呈した脺仮性菖胞に巨大総腸骨 動脈瘤を伴った 1 例. 日腹部救急医会誌 24 ： 1201-1205, 2004 


\title{
A CASE OF HEMOSUCCUS PANCREATICUS DUE TO HEMORRHAGE IN A PANCREATIC PSEUDOCYST
}

\author{
Hideaki HASHIDA, Kazuteru KOMURO, Nozomu IWASHIRO, \\ Masanori OHARA, Masanori ISHIZAKA and Satoshi KONDO* \\ Department of Surgery, National Hakodate Hospital
}

-Department of Surgical Oncology, Division of Cancer Medicine, Hokkaido University, Graduate School of Medicine

A 70-year-old man, who had been a heavy drinker and followed for chronic pancreatitis, was admitted to the hospital because of hematemesis in April 2003. There was a history of undergoing distal gastrectomy with Billroth II method for gastric ulcer. Abdominal CT scan revealed a splenic aneurysm $6 \mathrm{~cm}$ in diameter, but no abnormalities were detected by an endoscopic study. Since we could not observe the duodenal papilla to demonstrate any correlation between the splenic aneurysm and gastrointestinal hemorrhage, we determined to follow his clinical course. Thereafter he was admitted again because of hematemesis and anal bleeding in October. Endoscopic examination failed to identify bleeding site, however, anal bleeding persisted. Finally we diagnosed the case as gastrointestinal hemorrhage due to penetration of the splenic aneurysm into the pancreas, and performed the resection of the body and tail of pancreas with splenectomy. It was pathologically inferred that the splenic artery which lacked elastic fibers had penetrated a pancreatic pseudocyst to form a false aneurysm, leading to hemorrhage in the pancreatic duct.

In instances in which gastrointestinal hemorrhage occurs in the clinical course of chronic pancreatitis, hemosuccus pancreaticus, a hemorrhage via the pancreatic duct, must be kept in mind. 